Boston University School of Law

Scholarly Commons at Boston University School of Law

Faculty Scholarship

1997

The Bell Tolls for a Constitutional Right to Physician-Assisted

Suicide

George J. Annas

Follow this and additional works at: https://scholarship.law.bu.edu/faculty_scholarship

Part of the Health Law and Policy Commons 
Legal Issues in Medicine

\section{The Bell Tolls For a Constitutional Right to Physician-Assisted Suicide}

\author{
George J. AnNAS, J.D., M.P.H.
}

F OR Whom the Bell Tolls, Ernest Hemingway's novel about the Spanish Civil War, ends with its American hero, Robert Jordan, mortally wounded and trying to decide whether to commit suicide with a machine gun or risk capture by trying to retain consciousness long enough to cover the retreat of his comrades. Confronting his impending death, Jordan thinks, "Dying is only bad when it takes a long time and hurts so much that it humiliates you." Hemingway, one of the most American of American writers, committed suicide with a shotgun. Most suicides in the United States are committed with guns, but this country has no monopoly on suicide. Only in the United States, however, have groups of physicians gone to court to argue that suicide by drug overdose in the context of a doctorpatient relationship should have the status of a constitutional right.

The physicians, like Hemingway, describe suicide as a way to exercise control and assert autonomy. Many Americans die horrible deaths under medical care. The overall debate about how to make death better for patients and their families is complicated, multifaceted, and perhaps unresolvable. The debate about a constitutional right to physician-assisted suicide, on the other hand, was abruptly ended on June 26, 1997, the day the U.S. Supreme Court issued two unanimous rulings on the issue. ${ }^{1,2}$

\section{THE CIRCUIT-COURT OPINIONS}

The Court reviewed two opinions. The first, Compassion in Dying v. Washington, ${ }^{3}$ is the opinion of the Ninth Circuit Court of Appeals that the state of Washington's law against assisted suicide is unconstitutional as applied to physicians and their terminally ill patients because it violates a person's fundamental right to determine the time and manner of his or her death. The other opinion, Quillv. Vacco, ${ }^{4}$ is the opinion of the Second Circuit Court of Appeals that New York's laws against assisted suicide are unconstitutional when applied to physicians treating terminally ill patients who are not connected to lifesupport systems, because the laws do not provide these patients with equal protection. The court reasoned that patients connected to life-support systems can refuse to remain connected to them and thus hasten their deaths, whereas patients not con- nected to such systems cannot exercise the same legal right to hasten their deaths.

Because of the extremely high value Americans place on autonomy and because of our reasonable fear of pain, dependency, and loss of control during the process of dying, these opinions garnered much popular support. Nonetheless, the legal reasoning on which they were based was very weak. As I concluded in the Journal last year, "By failing to make such basic distinctions as those between the right to refuse treatment and the right to die, between suicide and assisted suicide, between law and ethics, and between ends and means, these courts virtually guarantee that their decisions will not be the last word on the subject." 5

The last word has now been written by the U.S. Supreme Court. The two unanimous rulings - by a Court that is usually divided in important cases are overwhelming and conclusive. Both opinions were written by Chief Justice William Rehnquist. Five justices also wrote concurring opinions.

There were two questions before the Court: Is there a constitutional right to assistance in suicide, and is the right to refuse treatment the same as a right to receive assistance in committing suicide? The first question was addressed in the appeal of the Ninth Circuit Court's opinion on Washington's law (Washington v. Glucksberg) ${ }^{1}$; the second was addressed in the appeal of the Second Circuit Court's opinion on New York's law (Vacco v. Quill). ${ }^{2}$

\section{WASHINGTON v. GLUCKSBERG}

The question before the Court in the appeal of the Ninth Circuit Court's opinion was "whether the 'liberty' specially protected by the Due Process Clause [of the Fourteenth Amendment] includes a right to commit suicide which itself includes a right

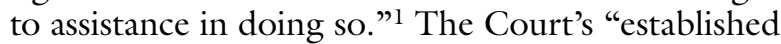
method" of defining a new constitutional right has two parts: the right must be "deeply rooted in this nation's history and tradition," or fundamental to ordered liberty, and must have a "careful description." (Rights fundamental to ordered liberty are, in legal parlance, the rights the justices see as essential to individual liberty in our society, even though they may not appear in the text of the Constitution.) The Court easily concluded that there is no historic tradition of treating suicide as a fundamental right, observing that to uphold such a right, the Court would "have to reverse centuries of legal doctrine and practice, and strike down the considered policy choice of almost every state." In a review of the history of laws against suicide and assisted suicide, the Court noted that suicide was decriminalized because it was impossible to punish the person and because it was seen as "unfair to punish the suicide's family for his wrongdoing." " Nonetheless, suicide "remained a grievous, though nonfelonious, wrong." 
The Court also reviewed the Ninth Circuit Court's reliance on Cruzan v. Director, Missouri Dept. of Health ${ }^{6}$ and Planned Parenthood v. Casey ${ }^{7}$ as sources of a new right to commit suicide. The Court characterized the case of Nancy Cruzan, a young woman in a persistent vegetative state whose parents wanted artificial feeding discontinued, as a case that involved the constitutional right to refuse medical treatment. This right is supported by the common-law doctrine of battery and informed consent and by "the long legal tradition protecting the decision to refuse unwanted medical treatment." In contrast, the Court noted, suicide "has never enjoyed similar legal protection," and the "two acts are widely and reasonably regarded as quite distinct." In Cruzan, the Court said, "We certainly gave no intimation" that the right to refuse treatment could be "somehow transmuted into a right to assistance in committing suicide." The Court dealt even more summarily with Casey, its most recent ruling on abortion, noting simply that the right to abortion does not support "the sweeping conclusion that any and all important, intimate, and personal decisions" are protected by the U.S. Constitution. ${ }^{1}$ Washington's law against assisted suicide withstands constitutional review, according to the Court, because it "does not violate the Fourteenth Amendment, either on its face or 'as applied to competent, terminally ill adults who wish to hasten their deaths by obtaining medication prescribed by their doctors." l

Because the Court concluded that no fundamental constitutional right to assisted suicide can be found in our nation's history or in the concept of ordered liberty, Washington had only to demonstrate that its assisted-suicide law was "rationally related to legitimate government interests." "The Court stated, "This requirement is unquestionably met here," and listed the following legitimate government interests: preserving human life; preventing suicide; protecting the integrity and ethics of the medical profession; protecting vulnerable groups from abuse, neglect, and mistakes; and preventing a start "down the path to voluntary and perhaps even involuntary euthanasia." As for the slippery slope, the Court noted that the Ninth Circuit Court's opinion seemed to permit surrogate decision making and, in some cases, lethal injection by a physician or family member. Therefore, the Court concluded, "It turns out that what is couched as a limited right to "physicianassisted suicide' is likely, in effect, a much broader license, which could prove extremely difficult to police and contain. Washington's ban on assisting suicide prevents such erosion."

\section{VACCO v. OUILL}

In the appeal of the Second Circuit Court's opinion, the question was whether the state of New York violated the equal-protection clause of the 14th Amendment by making it a crime to assist another person in committing suicide while permitting a patient to refuse life-saving treatment. The Supreme Court held that "it does not." 2

The equal-protection clause "embodies a general rule that States must treat like cases alike but may treat unlike cases accordingly." 2 Unless the statute "burdens a fundamental right or targets a suspect class," it will be upheld as long as it bears "a rational relation to some legitimate end." In Washington v. Glucksberg, the Court concluded that statutes outlawing assisted suicide do not infringe on fundamental rights or involve a suspect classification ${ }^{1}$ and are reasonably related to legitimate state interests. ${ }^{2}$ Therefore, the only real question in Vacco v. Quill was whether there is a rational difference between assisting a competent patient to commit suicide and withdrawing life-sustaining treatment from a competent patient who refuses to consent to its continuation. The Court answered this question at the outset, stating that New York's laws draw no distinctions among people, but instead treat all New York citizens the same: "Everyone, regardless of physical condition, is entitled, if competent, to refuse unwanted lifesaving medical treatment; no one is permitted to assist a suicide." 2

The lower court had concluded that since discontinuing or refusing life-sustaining medical treatment is "nothing more nor less than assisting suicide," laws prohibiting terminally ill people who are not receiving life-sustaining treatment from ending their lives with assistance deny them equal protection of the laws. ${ }^{4}$ The Supreme Court emphatically disagreed, specifically upholding as rational the distinction between withdrawing life-sustaining treatment and providing assistance with suicide, "a distinction widely recognized and endorsed in the medical profession and in our legal traditions." 2

The Court did not see as legally relevant the oftendiscussed distinctions between active and passive euthanasia or between the provision of artificial fluids and nutrition and other medical interventions. Instead, the Court explained, causation and intent are the two critical questions in this area of the criminal law. As to causation, the Court agreed with previous court rulings that "when a patient refuses life-sustaining medical treatment, he dies from an underlying fatal disease or pathology; but if a patient ingests lethal medication prescribed by a physician, he is killed by that medication." 2 Since medications prescribed for a legitimate medical purpose can also carry a risk of death, the primary distinction in cases involving such a risk is the physician's intent in prescribing or administering the medications. In the Court's words, when a physician provides aggressive palliative care, "in some cases, painkilling drugs may hasten a patient's death, but the physician's purpose and intent is, or may be, only to ease his patient's 
pain." 2 On the other hand, a doctor who assists a patient in committing suicide necessarily intends that the patient die. Similarly, a patient who commits suicide with a doctor's aid "necessarily has the specific intent to end his or her own life, while a patient who refuses or discontinues treatment might not."2

The Court noted that the law has historically distinguished between actions performed "because of" a given end and actions performed "in spite of" their unintended but foreseen consequences. Intent matters. The Court cited Judge Andrew Kleinfeld's example, in his dissenting opinion in Compassion in Dying v. Washington, ${ }^{3}$ of General Dwight Eisenhower, who ordered American soldiers into battle to liberate Europe, knowing that many would certainly die because of his order. ${ }^{2}$ If only the outcome, not Eisenhower's intent, had mattered, his order would have been the moral equivalent of ordering the murder of American soldiers at the hands of the Nazis. ${ }^{3}$

The Court observed that other courts have routinely made the distinction between refusing treatment and committing suicide, citing 34 prior decisions. Virtually all the states have also adopted the distinction in their statutes. Moreover, the Court said that in Cruzan, ${ }^{6}$ it had "recognized, at least implicitly, the distinction between letting a patient die and making that patient die." 2 The decision in Cruzan, the Court said, was based not on the recognition of any "general and abstract 'right to hasten death . . .' but on well-established, traditional rights to bodily integrity and freedom from unwanted touching." " The Court therefore (not surprisingly) concluded, "By permitting everyone to refuse unwanted medical treatment while prohibiting anyone from assisting a suicide, New York follows a longstanding and rational distinction." 2

The oral argument, which the Court heard on January 8 , focused on the example of "terminal sedation," 8 better described as sedation of the imminently dying. Although the Court's discussion of terminal sedation was relegated to a footnote, it is nonetheless important, because the Court applied to this example the reasoning outlined in its opinion. Even accepting the bizarre characterization of "terminal sedation" as "inducing barbiturate coma and then starving the person to death," the Court concluded that a state can legally countenance this form of palliative care if it is "based on informed consent and the double effect. Just as a state may prohibit assisting suicide while permitting patients to refuse unwanted lifesaving treatment, it may permit palliative care related to that refusal, which may have the foreseen but unintended 'double effect' of hastening the patient's death."

\section{THE CONCURRING OPINIONS}

There were five votes for each of the Court's opinions written by the Chief Justice (his own vote and the votes of Justices Sandra Day O'Connor, Antonin Scalia, Anthony Kennedy, and Clarence Thomas). All nine justices agreed that state laws prohibiting assisted suicide violate neither the due-process clause nor the equal-protection clause of the 14th Amendment, even as applied to physicians who prescribe overdoses of medications to competent, terminally ill patients who want to commit suicide. Nonetheless, five justices wrote concurring opinions to express additional or different reasons for this conclusion.

Justice O'Connor wrote a four-paragraph opinion, the only concurring opinion that any other justice agreed with, that suggests she believes patients near death may have a right to avoid "great" suffering. She made three points. First, in both Washington and New York, there are no laws preventing "a patient who is experiencing great pain" from "obtaining medication, from qualified physicians, to alleviate that suffering, even to the point of causing unconsciousness and hastening death." Second, the state's interests therefore justify prohibiting physician-assisted suicide. Third, state legislatures are the proper forum for an "extensive and serious evaluation of physician-assisted suicide and other related issues."

Justice Ruth Bader Ginsburg concurred with the Court's judgments in both opinions, "substantially for the reasons stated by Justice O'Connor." Justice Stephen Breyer also agreed with Justice O'Connor's opinion, "except insofar as it joins the majority." It is difficult to tell exactly what Justice Breyer meant, but he expressed concern about dying patients who receive insufficient medication for pain. He concluded that if a state ever prohibited physicians from providing sufficient palliative care, "including the administration of drugs as needed to avoid pain at the end of life," the Court would be presented with a different case "and might have to revisit its conclusions."

Justices John Paul Stevens and David Souter each wrote much longer concurring opinions. Justice Stevens concluded that it is possible that some other particular case (which he does not describe) might impose "an intolerable intrusion on the patient's freedom" by outlawing "the only possible means of preserving a dying patient's dignity and alleviating her intolerable suffering." Justice Souter seems to favor a right to end one's life with dignity that would apply not only to a person dying in pain but also to a person dying in a state of unacceptable "dependency and hopelessness." He nonetheless concluded that too little is known about the real-world effect of such a right for the Court to act, noting that "the case for the slippery slope is fairly made out here" and that "legislatures have superior opportunities to obtain the facts necessary for a judgment about the present controversy.” 


\section{CONSTITUTIONAL RIGHTS AND STATE INTERESTS}

In retrospect, it is easy to see why the right to physician-assisted suicide failed to gain constitutional recognition by the Supreme Court. First, to have upheld such a constitutional right, the Court would have had to find a constitutional right to suicide itself, and there is no historical or legal support for such a right. Second, the analogies the proponents of assisted suicide relied on - the right to have an abortion and the right to refuse treatment - are clearly distinguishable from the right to receive assistance with suicide. The Court remains deeply divided on the question of abortion, and notwithstanding some expansive language, Casey limited rather than expanded the abortion rights articulated in Roe v. Wade. ${ }^{9}$ The right to refuse treatment is deeply rooted in American law, and so are the principles of intent and causation in the criminal law. These principles distinguish suicide from the refusal of treatment, and assisted suicide from the withdrawal or withholding of treatment. These distinctions have been made by the courts in virtually every case since Quinlan, ${ }^{10}$ as well as by virtually every state legislature that has passed laws governing living wills and health care proxies. Third, to agree with the proponents of physician-assisted suicide, the Court would have had to limit any constitutional right it found to a small group of citizens (competent, pain-wracked, terminally ill people near death) and a particular method of suicide (an overdose of prescribed drugs) - limitations that have no basis in any constitutional principle.

To uphold the Washington and New York statutes outlawing assisted suicide, the Court had only to find that they were "rationally related to a legitimate state interest." Nonetheless, it seems reasonable to conclude that a majority of the justices would have permitted the states to continue to outlaw physician-assisted suicide even if they had thought it was a fundamental constitutional right, because at least some of these interests, especially avoiding a slide down the slippery slope to active euthanasia, are compelling. In the future, a state supreme court could thus find a limited right to assistance in suicide in the state's constitution but nonetheless uphold laws prohibiting assisted suicide because the state's interest in avoiding a slide from assisted suicide to euthanasia is compelling. In the first test of this kind, the Florida Supreme Court in July reversed a lower court's ruling that the right of privacy in Florida's constitution includes a right to a physician's assistance with suicide at the end of life. The Florida Supreme Court, in a five-to-one opinion, concluded that the privacy right is not this broad and that in any event, the state has at least three compelling interests that "clearly outweigh" the pe- titioner's desire for assistance in committing suicide: the preservation of life, the prevention of suicide, and maintenance of the ethical integrity of the medical profession. ${ }^{11}$

\section{DRUG PRESCRIPTIONS, CAUSATION, AND MORPHINE}

Although it explicitly endorsed the principle of the double effect, the Court did not directly apply the principle to writing drug prescriptions. Nonetheless, the logic of the opinion supports the conclusion that physicians can continue to write prescriptions for medically indicated drugs even with the knowledge that the patient might use the drugs to commit suicide, as long as the physician's intent is to prolong the patient's life or relieve pain. A physician who writes a drug prescription under these circumstances is, by legal definition, not engaged in physician-assisted suicide.

The Court's opinions can also be read as a strong endorsement of the views of the New York State Task Force on Life and the Law, whose 1994 report, When Death Is Sought, is cited frequently by the justices. ${ }^{12}$ The New York task force is important because it is the only long-standing, governmentsponsored, multidisciplinary group that has carefully studied the issue of physician-assisted suicide with a view toward proposing legislation, as well as the only authoritative group to report its conclusions both before and after the cases in the Second and Ninth Circuits were decided. ${ }^{12,13}$ The task force has been especially critical of the argument that the principle of autonomy justifies physician-assisted suicide. During the oral argument, for example, Justice Kennedy cited the task force's view that in this context, autonomy is "illusory" and that because the legalization of assisted suicide puts the vulnerable, the mentally ill, and the poor at risk, it could actually diminish choices, not increase them, and will increase fear.

The task force wrote a supplement to its 1994 report in April 1997. Although none of the justices cited this supplement, their opinions are consistent with its logic and conclusions. Two points that the task force makes are worth emphasizing. The first concerns legal causation, which is used by the courts to determine legal accountability, not simply to describe facts. In the context of a physician's care of a dying patient, many causes may contribute to the patient's death. But, as the task force properly observes, "When a variety of factual causes are necessary, but not individually sufficient, to bring about a particular result, the determination of which among them are properly cited as causative for legal purposes becomes a policy judgment, reflecting underlying assumptions about rights, duties, and moral blame."13,14 The Court's views of "rights, duties, and moral blame" explain why a physician is not held account- 
able as a causal agent for a death that occurs after life-sustaining treatment has been removed at the patient's insistence or while a patient is undergoing surgery. The courts have always recognized that the death of a patient under medical care does not occur in a moral vacuum.

The second point is emphasized in all the concurring opinions: "The effort to characterize morphine drips as a form of covert euthanasia is extremely misguided." 13 This characterization is a mistake for two reasons. The first reason is factual: morphine is often necessary for proper medical care, and it is never necessary to use it with "winks and nods." Death is not necessarily either hastened or intended when intravenous morphine is administered. ${ }^{15-17}$ When properly titrated, morphine usually does not hasten death at all, because of "the rapid development of tolerance to the respiratory depressant effects." 13 The second reason is that even in the cases in which increasing the morphine dosage may hasten the patient's death, this fact "does not make [its] use equivalent to assisted suicide or euthanasia." 13 The question is whether the risk of death is "justified in light of the paucity and undesirability of other options." 13 This point and the centrality of the principle of the double effect are well recognized in medical practice: "Medical treatment sometimes requires significant trade-offs, and acceptance of negative consequences for legitimate medical purposes is not equivalent to causing those consequences for their own sake." 13

\section{DEATH AND CONSTITUTIONAL LAW}

The quest for a constitutional right to physicianassisted suicide failed in the Supreme Court because it has no coherent basis in constitutional law. The right to refuse treatment, on the other hand, is a long-recognized right that physicians are legally and ethically required to honor. Patients have a right to insist that their bodies not be invaded without their consent. Likewise, the right to have an abortion is fundamentally different from the "right to die" in several respects. The right to have an abortion protects (rather than ends) a pregnant woman's life, health, and future, and it can be exercised by a clearly identifiable category of citizens (pregnant women). In addition, a physician must perform an abortion, because (unlike suicide) it is a medical procedure that cannot be safely or effectively performed by the woman herself.

In the wake of the Supreme Court's rulings, only physicians who really believe that there is no distinction between prescribing drugs that patients might use to commit suicide and giving them loaded guns with the intention that the patients shoot themselves need to reevaluate their medical practices and intentions to comply with the laws against homicide and assisted suicide. Doctors who provide palliative care with the primary intention of relieving pain and suffering, and with the patient's consent, are strongly encouraged to continue to do so by the Court. Indeed, at least five members of the Court seem to think there is something akin to a "right not to suffer," at least when death is imminent. Their concurring opinions can be read as a warning to the states not to adopt restrictive statutes that prohibit or inhibit physicians from doing everything in their medical power to prevent suffering.

These opinions make no change in the states' authority to outlaw or decriminalize assisted suicide. The real issue has never been what the states can do, but what they should do. There are proposals for pain-relief laws, but they are not, and should not be, limited to the terminally ill, and no new laws are needed to improve the care of the dying. Moreover, to the extent that physicians ask state legislatures for further regulation of prescriptions or the administration of medications near the end of life, treatment of the dying is likely to get worse, not better. ${ }^{18-20}$ There is no simple legal solution to our problems with addressing the needs of persons who are dying. ${ }^{21}$ The failed attempts to establish a constitutional right to physician-assisted suicide should be seen as a symptom of these problems, not a solution.

Hemingway ends his novel as Robert Jordan is waiting for an enemy "to reach the sunlit place where the first trees of the pine forest joined the green slope of the meadow" and feeling "his heart beating against the pine needle floor of the forest." It is possible to romanticize war, killing, and death only by turning away from them and describing something else. The bell has tolled for a constitutional right to physician-assisted suicide, but it should awaken us to the challenge that remains: to face and deal directly with death and dying.

Professor Annas was a coauthor with Leonard Glantz and Wendy Mariner of the Bioethics Professors' amicus brief, which argued that neither the right to refuse treatment nor the right to abortion provided a constitutional precedent supporting a right to physician-assisted suicide. The full text of the brief is available on the World Wide Web (see http://www-busph. bu.edu/Depts/HealthLaw).

\section{REFERENCES}

1. Washington v. Glucksberg, 117 S. Ct. 2302 (1997).

2. Vacco v. Quill, 117 S. Ct. 2293 (1997).

3. Compassion in Dying v. Washington, 79 F.3d 790 (9th Cir. 1996).

4. Quill v. Vacco, 80 F.3d 716 (2d Cir. 1996).

5. Annas GJ. The promised end - constitutional aspects of physicianassisted suicide. N Engl J Med 1996;335:683-7.

6. Cruzan v. Director, Missouri Dept. of Health, 497 U.S. 261 (1990).

7. Planned Parenthood v. Casey, 505 U.S. 833 (1992)

8. Rousseau P. Terminal sedation in the care of dying patients. Arch Intern Med 1996;156:1785-6.

9. Roe v. Wade, 410 U.S. 113 (1973).

10. In re Quinlan, 355 A.2d 647 (N.J. 1976).

11. Krischer v. McIver, 697 So. 2 d 97 (Fla. 1997)

12. When death is sought: assisted suicide and euthanasia in the medical context. New York: New York State Task Force on Life and the Law, 1994

13. When death is sought: assisted suicide and euthanasia in the medical context: supplement to report. New York: New York State Task Force on Life and the Law, April 1997. 
14. Hart HLA, Honore T. Causation in the law. 2nd ed. Oxford, England: Clarendon Press, 1985.

15. Foley KM. Controversies in cancer pain: medical perspectives. Cancer 1989;63:Suppl:2257-65

16. Wilson WC, Smedira NG, Fink C, McDowell JA, Luce JM. Ordering and administration of sedatives and analgesics during the withholding and withdrawal of life support from critically ill patients. JAMA 1992;267:94953.

17. President's Commission for the Study of Ethical Problems in Medicine and Biomedical Behavioral Research. Deciding to forego life-sustaining treatment: a report on the ethical, medical, and legal issues in treatment decisions. Washington, D.C.: Government Printing Office, 1983.
18. Annas GJ. Death by prescription - the Oregon initiative. N Engl J Med 1994;331:1240-3.

19. Joranson DE, Gilson AM. Improving pain management through policy making and education for medical regulators. J Law Med Ethics 1996; 24:344-7.

20. Johnson $\mathrm{SH}$. Disciplinary actions and pain relief: analysis of the Pain Relief Act. J Law Med Ethics 1996;24:319-27.

21. Committee on Care at the End of Life, Institute of Medicine. Ap proaching death: improving care at the end of life. Washington, D.C.: National Academy Press, 1997.

(C)1997, Massachusetts Medical Society. 